УДК 347.672:341.954

DOI https://doi.org/10.32837/pyuv.v0i5.930

\author{
М.O. Михайлів \\ orcid.org/0000 000217027432 \\ кандидат юридичних наук, доиент, \\ доцент кафедри цивільного права та процесу \\ Львівського національного університету імені Івана Франка
}

\title{
МІЖНАРОДНІ ДОГОВОРИ ЯК ДЖЕРЕЛО ПРАВОВОГО РЕГУ ЛЮВАННЯ СПАДКУВАННЯ ЗА ЗАПОВІТОМ В МІЖНАРОДНОМУ ПРИВАТНОМУ ПРАВІ
}

Постановка проблеми. Найбільш ефективним способом уніфікації норм у сфері спадкування за заповітом у міжнародному приватному праві є міжнародні договори. Вони допомагають усунути розбіжності між законодавством держав світу у сфері спадкування 3 іноземним елементом. Проте кількість таких договорів є порівняно невеликою, а імплементація норм міжнародних договорів у державах, що їх підписали, - незначною. У зв'язку із цим дослідження міжнародних договорів як засобу правового регулювання відносин міжнародного спадкування є актуальним, що сприятиме всебічному дослідженню змісту таких норм та виокремленню проблем, пов'язаних із правовим регулюванням відносин спадкування за заповітом з іноземним елементом.

Аналіз останніх досліджень i публікацій. Питанням правового регулювання відносин спадкування за заповітом у міжнародному приватному праві приділяли увагу такі українські та іноземні вчені, як Г.В. Галущенко, І.Г. Гетьман-Павлова, I.A. Діковська, А.С. Довгерт, О.О. Кармаза, В.І. Кисіль, Л.А. Лунц, І.Г. Медведєв, Н.В. Орлова, А.А. Рубанов, У.О. Слабошпицька, А.А. Степанюк, С.А. Фурса, Т.С. Хороша та ін.

Метою статті $\epsilon$ аналіз норм міжнародних договорів у сфері спадкування за заповітом в міжнародному приватному праві та визначення місця, яке вони займають серед інших джерел міжнародного приватного права у відносинах міжнародного спадкування за заповітом. Виокремити проблеми правового регулювання міжнародних спадкових відносин за заповітом у різного виду міжнародних договорах та запропонувати шляхи їх вирішення.

Виклад основного матеріалу. Правове регулювання питань спадкування за заповітом державами здійснюється по-різному. Це стосується розбіжності як між матеріальними, так і між колізійними нормами національного законодавства держав. Уникнути таких проблем можна шляхом створення та застосування уніфікованих норм. Тому найбільш ефективним способом уніфікації норм у сфері спадкування за заповітом $\epsilon$ прийняття міжнародних договорів.

Як зазначає А.А. Рубанов, багатосторонні угоди 3 питань спадкування - це найбільш адек- ватна юридична форма для розвитку відносин між країнами. Він називав два шляхи переходу до багатостороннього регулювання: укладення багатосторонніх угод про правову допомогу та укладення особливої багатосторонньої угоди з питань спадкування [20, с. 23-24].

Кількість багатосторонніх міжнародних договорів у сфері спадкування є порівняно невеликою, проте, на думку B.I. Кисіля, більший успіх мали зусилля щодо уніфікації норм про спадкування на регіональному рівні (Європейські співтовариства, країни Латинської Америки, країни СНД). Однак чи не найбільш дієвим механізмом міжнародного правового регулювання спадкових відносин сьогодні виступають двосторонні міжнародні договори [13, с. 167].

Важливим джерелом регулювання міжнародних спадкових правовідносин є двосторонні договори про правову допомогу, які містять колізійні та матеріально-правові приписи із відповідних питань [4, с. 117-135].

За часів незалежності Україна уклала двосторонні договори про правову допомогу в цивільних та сімейних справах із Китайською Народною Республікою (1992р.), Литвою (1993р.), Польщею (1993р.), Грузією (1995р.), Латвією (1995 р.), Молдовою (1995 р.), Естонією (1996 р.), Македонією (2000р.), Румунією (2002р.), Кіпром (2005 р.) та іншими державами. Чинними для України залишаються договори, укладені між Радянським Союзом та Албанією (1958 р.), Болгарією (1975 р.), В’єтнамом (1981 р.), Іраком (1973р.), КНДР (1957р.), Республікою Куба (1957 р.), Монголією (1958 р.), Грецією (1981 р.), Кіпром (1984р.), Сирійською Арабською Республікою (1984p.) та ін. [5, с. 367].

У договорі між Україною і Республікою Польща про правову допомогу та правові відносини у цивільних і кримінальних справах [6] регулюванню спадкових відносин присвячено розділ IV. Так, здатність до складення або відміни заповіту, а також правові наслідки недоліків волевиявлення визначаються законодавством тієї Договірної Сторони, громадянином якої був заповідач в момент складення або відміни заповіту. Спосіб складення або відміни заповіту визначається законодавством 
тієї Договірної Сторони, громадянином якої був заповідач у момент складення або відміни заповіту. Але достатнім є дотримання законодавства тієї Договірної Сторони, на території якої заповіт був складений або відмінений.

Крім того, договір містить положення щодо відкриття і оголошення заповіту. Стаття 40 встановлює, що заповіт відкриває і оголошує компетентний орган тієї Договірної Сторони, на території якої знаходиться заповіт. Засвідчена копія заповіту, а також копія протоколу відкриття і оголошення заповіту пересилаються відповідному органу, до компетенції якого належить ведення спадкової справи. Варто зазначити, що ведення спадкових справ належить до компетенції органів держави, громадянином якої був спадкодавець.

Дещо інший підхід до компетенції у справах про спадкування закріплено у договорі між Україною та Румунією про правову допомогу та правові відносини у цивільних справах [9], стаття 37 якого встановлює, що спадкові справи щодо рухомого майна належать до компетенції установ юстиції тієї Договірної Сторони, громадянином якої був спадкодавець в момент смерті, а щодо нерухомого майна - до компетенції установ юстиції тієї Договірної Сторони, на території якої нерухоме майно розташоване. Така ж колізійна прив'язка закріплена у договорі між Україною та КНДР (ст. 36) [8] та Чеською Республікою (ст. 41) [10].

Стаття 36 Договору між Україною та Естонською Республікою про правову допомогу та правові відносини у цивільних та кримінальних справах [7] передбачає, що форма заповіту визначається законодавством Договірної Сторони, громадянином якої був спадкоємець на момент складання заповіту. Однак достатньо, щоб було дотримано законодавство Договірної Сторони, на території якої був складений заповіт. Це положення застосовується і щодо скасування заповіту. Стаття 37 цього договору визначає компетенцію у справах про спадкування. Так, провадження у справах про спадкування рухомого майна здійснюють установи Договірної Сторони, на теритоpiї якої спадкоємець мав останнє постійне місце проживання. Якщо все рухоме спадкове майно знаходиться на території Договірної Сторони, де спадкодавець не мав останнього постійного місця проживання, тоді за заявою спадкоємця або відказоодержувача, якщо 3 цим згодні всі спадкоємці, провадження по справі про успадкування проводять установи цієї Договірної Сторони. Провадження у справах про спадкування нерухомого майна провадять установи Договірної Сторони, на території якої знаходиться це майно.

Згідно з договорами про правову допомогу, які уклала Україна з КНДР (ст. 35), Румунією (ст. 36), Чеською республікою (ст. 40), договором між СРСР та ФРН (ст. 36) та іншими здатність особи складати або скасовувати заповіт, а також визначення правових наслідків недоліків волевиявлення, встановлюється законодавством тієї Договірної Сторони, громадянином якої був заповідач на момент складання або скасування заповіту. Форма складання або скасування заповіту визначається законодавством тієї Договірної Сторони, громадянином якої був заповідач на момент складання або скасування заповіту. Проте достатньо, щоб було дотримане законодавство Договірної Сторони, на території якої було складено або скасовано, змінено заповіт [11].

Таким чином, двосторонні договори про правову допомогу, які містять колізійні норми щодо заповідальної здатності, надають перевагу не праву держави, у якій заповідач мав місце проживання, а праву держави, громадянином якої останній був на момент складення чи скасування заповіту.

Багатосторонні конвенції регулюють лише окремі питання спадкування, оскільки значні розбіжності, які існують у внутрішньодержавному регулюванні, становлять певні труднощі щодо створення уніфікованих норм. Складність уніфікації спадкових відносин, які відрізняються значним консерватизмом, зумовлюе незначну кількість міжнародних договорів у цій сфері.

До багатосторонніх конвенцій, якими здійснено спроби уніфікації у сфері спадкування за заповітом, насамперед слід віднести:

1. Гаазьку конвениію про колізї законів стосовно форми спадкових розпоряджень від 5 жовтня 1961 року [3].

Україна із застереженнями приєдналася до цієї Конвенції 17.12.2009 року. Для України Конвенція набула чинності 14 травня 2011 року. Цим актом передбачено широкий вибір колізійних прив'язок. Так, ст. 1 передбачає, що заповіт є дійсним стосовно форми, якщо його форма відповідає внутрішньому законодавству держави:

a) де заповідач його склав, або

б) громадянства заповідача на момент складення заповіту чи на момент його смерті, або

в) постійного місця проживання заповідача на момент складення заповіту чи на момент його смерті, або

г) звичайного місця проживання заповідача на момент складення заповіту чи на момент його смерті, або

г) настільки, наскільки це стосується нерухомості, - iї місцезнаходження.

Україна приєдналася до Конвенції із трьома застереженнями. Так, відповідно до Конвенції, визначення того, чи мав заповідач постійне місце проживання в певному місці, регулюється правом цього місця. При цьому Україна зробила застереження, згідно з яким залишила за собою право визначати місце постійного проживання 
заповідача згідно із законом суду (lex fori). Крім цього, Україна залишила за собою право не визнавати заповіти, вчинені громадянами України в усній формі, окрім тих, які вчинені за виняткових обставин.

2. Вашингтонську конвениію, що передбачає уніфікований закон про міжнародний заповіт від 26 жовтня 1973 року [2].

Ця конвенція є єдиним прикладом уніфікації матеріальних норм спадкового права, інші конвенції містять уніфіковані колізійні норми щодо спадкування [12, с. 13].

Конвенція містить зобов'язання держав-учасниць включити у їх внутрішні законодавства положення, що стосуються типової форми міжнародного заповіту. Заповіт, складений у такій формі, вважається дійсним з погляду форми незалежно від місця його складення, місця знаходження майна, громадянства, постійного чи тимчасового місця проживання спадкодавця.

Фактично «міжнародний заповіт» є формою, розробленою із урахуванням світових законодавств та практики у сфері спадкування. Такий заповіт повинен мати письмову форму, причому не обов'язково, щоб він був написаний самим заповідачем, - допускається використання технічних засобів. Якщо особа не здатна скласти заповіт самостійно, це може бути зроблено з їі слів іншою особою. Заповідач у присутності двох свідків і особи, яка має посвідчити заповіт, проголошує, що цей документ є його заповітом, і зміст такого заповіту йому відомий. Ознайомлення свідків та уповноваженої особи зі змістом заповіту не є обов'язковим. Типовий закон встановлює лояльні вимоги до здатності бути свідком, встановлюються вимоги щодо посвідчення заповітів тощо [5, с. 362].

3. Конвениію про право, що застосовується до спадкування майна померлих осіб, прийняту у Гаазі 1 серпня 1989 р. [15]. Конвенція так і не набула чинності. Ця Конвенція визначає право, що застосовується до спадкування майна померлих осіб. Конвенція не застосовується щодо визначення: а) форм розпорядження майном після смерті; б) здатності до розпорядження майном після смерті; в) питань, що стосуються спільної власності подружжя; г) майнових прав, інтересів або активів, створених або переданих іншим способом, ніж у спадок, наприклад, у спільній власності 3 правом на виживання (survival), пенсійних планів, договорів страхування або механізмів аналогічного характеру. Таким чином, Конвенція не застосовується до визначення форми заповіту і заповідальної дієздатності, проте є важливим кроком до уніфікації спадкових відносин.

Стаття 3 цієї конвенції встановлює, що спадкування регулюється правом держави, в якій спадкодавець на момент його смерті мав постійне місце проживання, за умови, що він був громадянином цієї держави. Спадкування також регулюється правом держави, в якій спадкодавець на момент його смерті мав постійне місце проживання, але за умови, що він проживав у цій державі не менше 5 років, що безпосередньо передували його смерті. Проте у виняткових випадках, якщо в момент його смерті він був явно більш тісно пов'язаний 3 державою, громадянином якої він був, застосовується право цієї держави. У всіх інших випадках до спадкування застосовуватиметься право держави, громадянином якої був спадкодавець на момент смерті, якщо на цей момент він більш тісно не був пов'язаний з іншою державою.

Конвенція також передбачає можливість спадкодавця обрати (designate) право, яке застосовуватиметься до спадкування усього його майна. Але такий вибір матиме силу лише у разі, якщо на цей момент чи на момент його смерті він був громадянином цієї держави чи мав у ній постійне проживання. Такий вибір повинен бути здійснений у формі, що відповідає формальним вимогам щодо розпорядження майном на випадок смерті. Чинність такого вибору визначається за правом обраної (designated) держави. Причому спадкодавець може обрати право однієї чи декількох держав, що регулюють спадкування окремих видів майна.

Дещо успішнішими є уніфікації спадкових норм, що стосуються заповітів, здійснені на регіональному рівні, серед яких найвідомішими є:

1. Кодекс міжнародного приватного права [14], прийнятий 20 лютого 1928 року на VI міжнародній американській конференції у Гавані (Кодекс Бустаманте). Розділи III-V цього Кодексу присвячено саме регулюванню спадкових відносин.

Основною колізійною прив'язкою, з якої виходить Кодекс у питаннях міжнародного спадкування, є особистий закон (спадкодавця або спадкоємця), незалежно від того, з чого складається спадкове майно та де його місце знаходження. Згідно зі ст. 7 Кодексу, кожна договірна держава застосовує у якості особистого закону закон доміцилію або закон громадянства відповідно до вимог свого внутрішнього законодавства.

Особистому закону спадкодавця Кодекс підпорядковує загальні питання спадкування за законом і за заповітом, здатність заповідати (ст. 146), процедуру, умови і наслідки відкликання заповіту (ст. 151), призначення спадкоємця (ст. 154). Питання здатності бути спадкоємцем за заповітом або за законом (ст. 152), а також здатність вимагати та здійснювати розподіл спадкового майна (ст. 161) відповідно до Кодексу, регулюються особистим законом спадкоємця.

Кодексом передбачено винятки із загальних правил, коли відповідні правовідносини визнаються такими, що підпорядковані міжнародному публічному порядку (що фактично 
означає обов'язковість регулювання таких прав та обов'язків правом держави, на території якої вони мають бути реалізовані). Питання, що стосуються міжнародного публічного порядку, охоплюють: правило, згідно з яким права на спадщину після будь-якої особи переходять з моменту їі смерті (ст. 145), норми, які забороняють взаємні, усні та олографічні заповіти (ст. 148), правила про форму заповітів та їх недійсність (ст. 149, 150), випадки нездатності (недостойності) бути спадкоємцем (ст. 153). Кодекс містить цікаві положення щодо збереження дійсності заповітів душевно хворих осіб (встановлено, що кожна держава, відповідно до свого територіального закону, буде констатувати, чи перебував душевно хворий заповідач у "світлому проміжку»), а також щодо особливостей стану вагітної вдови спадкодавця (у випадку, коли вдова залишається вагітною, заходи щодо охорони спадщини регулюються законодавством місця її перебування) [5, с. 366].

2. Конвениія про правові відносини і правову допологу у иивільних, сілейних та крилінальних справах [16], підписана у Мінську 22 січня 1993 року. Конвенція застосовується до тих справ про міжнародне спадкування, які зачіпають правопорядки країн - учасників СНД за умови відсутності між ними відповідного двостороннього договору [1, с. 416].

Відповідно до ст. 47 Конвенції, здатність особи до складання і скасування заповіту, а також форма заповіту і його скасування визначаються за правом тієї країни, де заповідач мав місце проживання в момент складання акта. Однак заповіт або його скасування не можуть бути визнані недійсними внаслідок недотримання форми, якщо остання задовольняє вимоги права місця його складання. Конвенція також містить важливі положення про компетенцію по справах про спадщину, яка залежить від виду спадкового майна. Так, стаття 48 закріплює положення, що провадження у справах про спадкування рухомого майна компетентні вести установи Договірної Сторони, на території якої мав місце проживання спадкодавець у момент своєї смерті, а щодо нерухомого майна - установи Договірної Сторони, на території якої знаходиться майно. Стаття 49 закріплює положення про компетенцію дипломатичного представництва та консульської установи по справах про спадщину. При цьому дипломатичним представництвам або консульським установам не потрібно спеціального доручення, щоб представляти в установах інших Договірних Сторін громадян своєї держави, якщо вони відсутні або не призначили представника.

3. Конвениія Ради Європи (Базельська конвениія) про запровадження систели реєстраиї заповітів [17] від 16 травня 1972 року. Конвенція набрала чинності для України 31 грудня 2010 року.
Конвенцією передбачено створення у кожній державі-учасниці системи, що дає змогу заповідачеві зареєструвати свій заповіт і уникнути ситуації, коли про існування заповіту не буде відомо в іншій державі. У кожній державі призначається один чи більше органів, відповідальних за реєстрацію, передбачену цією Конвенцією, та за надання відповідей на запити про надання інформації.

Реєстрації в договірних державах підлягають:

(a) посвідчені заповіти, пред'явлені нотаріусу, державному органу чи будь-якій особі, які за законом даної держави мають право реєструвати їх, а також інші заповіти, передані на зберігання органу чи особі, які уповноважені законом приймати такі заповіти на зберігання, коли при цьому складається офіційний документ про прийняття заповіту на зберігання;

(б) власноручно складені заповіти, передані на зберігання нотаріусу, державному органу чи будьякій особі, які за законом даної держави мають право приймати їх на зберігання, при цьому офіційний документ про прийняття заповіту на зберігання не складається, якщо закон дозволяє таку передачу. Заповідач має право відмовитися від реєстрації заповіту, якщо зазначений закон не забороняє такої відмови.

Відкликання, скасування та інші зміни до заповітів, зареєстрованих відповідно до Конвенції, також підлягають реєстрації, якщо їх складено за формою, яка вимагає обов'язкової реєстраціï.

Протягом життя заповідача факт реєстрації заповіту розголошенню не підлягає. Після смерті заповідача будь-яка особа може отримати відомості щодо заповіту за умови пред'явлення витягу зі свідоцтва про смерть чи будь-якого іншого прийнятного документа, що підтверджує факт смерті заповідача.

Відповідно до умов Конвенції, у кожній з договірних держав призначається орган, уповноважений передавати іншим державам інформацію щодо записів у реєстрі заповітів, а також приймати й передавати запити від органів, призначених в інших державах. В Україні ці функції покладено на Міністерство юстиції України.

Привертає до себе увагу той факт, що уряд Туреччини уповноважив на реєстрацію та надання відомостей про заповіти безпосередньо Асоціацію нотаріусів Туреччини (Turkiye Noterler Birligi), про що свідчить відповідна заява Туреччини, яка додається до Конвенції. Аналогічно Італійська Республіка призначила національним органом керівника нотаріального архіву ("Amministrazione Archivi Notarili nella persona del Direttore avente qualifica di Conservatore del registro generale dei Testamenti”). В Іспанії, Королівстві Нідерланди такі повноваження виконує Міністерство юстиції (Ministerio de Justicia, Secretaria General 
Tecnica). Національним органом, призначеним для Республіки Естонія, є відділ реєстрації спадщин $[18$, с. 170$]$.

Таким чином, із прийняттям Базельської Конвенції встановлюється достатньо ефективна система обміну інформацією про заповіти, що спрощує процедури міжнародного регулювання у цій сфері [5, с. 365].

4. Реглалент Європейського Парламенту та Ради Європейського Союзу №650/2012 від 4 липня 2012 року про компетенцію, застосовуване право, визнання і виконання рішень, прийняття і виконання нотаріальних актів з питань спадкування, а також про створення європейського свідоцтва про спадкування (так званий Реглалент «Рим IV») [19]. Сфера дії цього Регламенту поширюється на всі цивільно-правові аспекти спадкування майна померлих, а саме: усі форми передачі майна, прав та обов'язків з причин смерті, як добровільної передачі на підставі розпорядження на випадок смерті, так і передачі шляхом спадкування без заповіту.

Регламент встановлює, що за загальним правилом до регулювання спадкових правовідносин застосовується право держави, у якій спадкодавець мав постійне місце проживання на момент смерті. Проте заповідач має право обрати право держави, громадянином якої він був на момент такого вибору чи на момент смерті. За цим правом визначається, зокрема, здатність особи на складення заповіту.

Слід відзначити, що уніфікований акт закріплює також систему альтернативних колізійних прив'язок, що стосуються формальної дійсності заповіту. Так, згідно із статтею 27 Регламенту, заповідальне розпорядження, складене у письмовій формі, є дійсним з точки зору його форми, якщо остання узгоджується з правом:

a) держави, в якій було складено заповідальне розпорядження;

б) держави, громадянином якої є спадкодавець або хоча б одна із осіб, яких стосується заповідальне розпорядження;

в) держави, в якій спадкодавець або хоча б одна із осіб, яких стосується заповідальне розпорядження, має свій доміцилій;

г) держави, в якій спадкодавець або хоча б одна із осіб, яких стосується заповідальне розпорядження, має своє звичайне місце проживання, або

r) держави, в якій розміщене нерухоме майно.

При цьому доміцилій, громадянство, звичайне місце проживання може визначатися або на момент складання заповідального розпорядження, або на час смерті.

Таким чином, у питаннях регулювання форми заповідальних розпоряджень положення Регламенту майже у повному обсязі кореспондуються із приписами Гаазької конвенції 1961 року про колізії законів, які стосуються форми заповітів [21, c. 103].

Як підсумок пропонуємо провести класифікацію міжнародних договорів у сфері спадкування за заповітом за такими критеріями:

1. За кількісним складом:

- двосторонні;

- багатосторонні (регіональні, універсальні).

2. За нормами, які містять міжнародні договори:

- колізійні норми у сфері спадкування за заповітом;

- матеріальні норми у сфері спадкування за заповітом;

- як колізійні норми у сфері спадкування за заповітом так і матеріальні норми (змішані норми).

3. За сферою дії міжнародні договори:

- загальні, наприклад у сфері надання правової допомоги у цивільних справах;

- спеціальні, що прийняті у сфері спадкування за заповітом.

Висновки. Отже, уніфікація норм у сфері спадкування за заповітом здійснюється на основі багатосторонніх конвенцій (Гаазька конвенція від 5 жовтня 1961 р., Вашингтонська конвенція від 26 жовтня 1973 р., Гаазька конвенція від 1 серпня 1989 р.), актів регіонального характеру (Кодекс Бустаманте від 20 лютого 1928 р., Мінська Конвенція від 22 січня 1993 р., Базельська Конвенція від 16 травня 1972 р., Регламент «Рим IV» від 4 липня 2012 р.) та двосторонніх міжнародних договорів у сфері надання правової допомоги. Проте найбільший масив уніфікованих норм міжнародного приватного права стосовно спадкування за заповітом міститься у двосторонніх міжнародних договорах про правову допомогу, які, як правило, надають перевагу праву держави, громадянином якої був заповідач. На сьогодні уніфікація в галузі спадкового права стосується лише колізійних норм, оскільки уніфікація самих матеріальних норм $€$ надзвичайно складною та практично неможливою через значні відмінності у регулюванні цих відносин у законодавстві різних держав.

\section{Jimepamypa}

1. Абраменков М.С. Наследственное право: ученик для магистров/ М.С. Абраменков, П. В. Чугунов; отв. ред. В.А. Белов. Москва : Издательство Юрайт, 2013. $423 \mathrm{c}$.

2. Вашингтонська конвенція, що передбачає уніфікований закон про міжнародний заповіт від 26.10 .1973 p. URL: http://zakon2.rada.gov.ua/laws/ show/995 b13.

3. Гаазька конвенція про колізії законів стосовно форми спадкових розпоряджень від 5 жовтня $1961 \mathrm{p}$. URL: http://zakon2.rada.gov.ua/laws/show/995_424.

4. Галущенко В. Г. Питання міжнародного приватного права у міжнародних договорах України про 
правову допомогу. Київ: Видавництво «Юстініан», 2005. $472 \mathrm{c}$.

5. Довгерт А. С. Міжнародне приватне право: особлива частина: підручник / А. С. Довгерт, В. І. Кисіль. Київ: Алерта, 2013. 400 с.

6. Договір між Україною і Республікою Польща про правову допомогу та правові відносини у цивільних і кримінальних справах від 23.05.1993 p. URL: http://zakon5.rada.gov.ua/laws/show/616_174/ print1445454375308313.

7. Договір між Україною та Естонською Республікою про правову допомогу та правові відносини у цивільних та кримінальних справах від 15.02.1995 p. URL: http://zakon0.rada.gov.ua/laws/show/233_659/ print1368621876714322.

8. Договір між Україною та Корейською Народно-Демократичною Республікою про правову допомогу в цивільних та кримінальних справах від 13.10.2003 р. URL: http://zakon2.rada.gov.ua/laws/show/408_012/ print1443093674069567.

9. Договір між Україною та Румунією про правову допомогу та правові відносини цивільних справах від 02.06.1997 p. URL: http://zakon1.rada.gov.ua/ laws/show/642 029/print1433745184414535.

10. Договір між Україною та Чеською Республікою про правову допомогу в цивільних справах від 28.05.2001 p. URL: http://zakon2.rada.gov.ua/laws/ show/203 018/print1443093674069567.

11. Договор между Союзом Советских Социалистических Республик и Германской Демократической Республикой о правовой помощи по гражданским, семейным и уголовным делам от 28.11.1957 p. URL: http://zakon5.rada.gov.ua/laws/show/276 400/ print1443616183692613.

12. Кармаза О. О. Спадкування у сучасному міжнародному приватному праві : автореф. дис. ... канд юрид. наук. Київ, 2006. 18 с.

13. Кисіль В. Спадкові відносини в сучасному міжнародному приватному праві. Право України. 2013. № 7. C. $154-182$.

14. Кодекс міжнародного приватного права від 20 лютого 1928 року URL: http://zakon2.rada.gov.ua/ laws/show/995 419/print1444043974603927.

15. Конвенція про право, що застосовується до спадкування майна померлих осіб, прийнята у Гаазі 1 серпня 1989p. URL: https://assets.hcch.net/ docs/5af01fa4-c81f-4e99-b214-64421135069f.pdf.

16. Конвенція про правові відносини і правову допомогу у цивільних, сімейних та кримінальних справах від 22 січня 1993 року. URL: http://zakon3.rada.gov.ua/ laws/show/997 009/print1444315331426685.

17. Конвенція Ради Європи (Базельська конвенція) про запровадження системи реєстраціі заповітів від 16 травня 1972 року URL: http:// zakon5.rada.gov.ua/laws/show/994 678.

18. Криштопа О. М. Про запровадження в Україні Базельської конвенції щодо системи реєстрації заповітів: актуальні питання. Вісник Вищої ради юстииї. 2011. № 3(7). C. 168-177.

19. Regulation (EU) № 650/2012 of the European Parliament and of the Council of 4 July 2012 on jurisdiction, applicable law, recognition and enforcement of decisions and acceptance and enforcement of authentic instruments in matters of succession and on the creation of a European Certificate of Succession. Official Journal of the European Union L 201. 2012. 27 July. URL: http://eur-lex.europa.eu/LexUriServ/LexUriServ.do?u $\mathrm{ri}=0 \mathrm{~J}: \mathrm{L}: 2012: 201: 0107: 0134: \mathrm{EN}: \mathrm{PDF}$.

20. Рубанов А.А. Наследование в международном частном праве (отношения между социалистическими странами). Москва : Наука, 1972. 287 с.
21. Слабошпицька У.О. Система колізійних норм Риму IV: основні положення Регламенту (EC) № 650/2012. Науковий вісник УжНУ. Серія «Право». 2015. № 34. Tом 1. C.101-105.

\section{Анотація}

Михайлів М. О. Міжнародні договори як джерело правового регулювання спадкування за заповітом в міжнародному приватному праві. - Стаття.

У статті розглянуто питання правового регулювання відносин спадкування за заповітом з іноземним елементом за допомогою норм міжнародних договорів. Проведено аналіз різних видів міжнародних договорів з питань правового регулювання спадкування за заповітом 3 іноземним елементом, надано перелік таких договорів та проведено їх коротку характеристику. У статті звертається увага на те, що багатосторонніх міжнародних договорів у сфері міжнародного спадкування за заповітом є порівняно небагато, у зв'язку із чим більший успіх мала уніфікація колізійних норм щодо спадкування на регіональному рівні та у спосіб прийняття двосторонніх міжнародних договорів про правову допомогу.

У статті звертається увага на те, що багатосторонні конвенції регулюють лише окремі питання спадкування, оскільки значні розбіжності, які існують у внутрішньодержавному регулюванні, становлять певні труднощі під час створення уніфікованих норм.

У статті закцентовано увагу на різних підходах щодо колізійного регулювання питань спадкування за законом в двосторонніх міжнародних договорах про правову допомогу. Зокрема, міжнародні договори про правову допомогу, які містять колізійні норми щодо заповідальної здатності, надають перевагу не праву держави, у якій заповідач мав місце проживання, а праву держави, громадянином якої останній був на момент складення чи скасування заповіту.

Провівши аналіз норм Регламенту ЄС № 650/2012 від 4 липня 2012 року, звертається увага на те, що за загальним правилом до регулювання спадкових правовідносин застосовується право держави, у якій спадкодавець мав постійне місце проживання на момент смерті. Проте заповідач має право обрати право держави, громадянином якої він був на момент такого вибору чи на момент смерті. За цим правом визначається, зокрема, здатність особи на складення заповіту.

Як підсумок запропоновано класифікацію міжнародних договорів у сфері спадкування за заповітом за такими критеріями, як кількісний склад, види норм, які містяться в таких міжнародних договорах, та сфера ïx дiï.

Ключові слова: спадкування, міжнародний договір, спадкування за заповітом, міжнародний договір у сфері надання правової допомоги.

\section{Summary}

Mykhayliv M. O. International agreements as a source of legal regulation of testamentary inheritance in private international law. - Article.

The article considers the issue of legal regulation of inheritance by will with a foreign element with the help of international agreements. Various types of international agreements on the legal regulation of inheritance by will with a foreign element are analyzed, a list of such agreements and their brief description are provided. The article draws attention to the fact that there are relatively few multilateral international treaties in the 
field of international inheritance by will, due to which the unification of conflict rules on inheritance at the regional level and in the way of adopting bilateral international treaties on legal assistance has been more successful.

The article also draws attention to the fact that multilateral conventions regulate only certain issues of inheritance, as significant differences that exist in domestic regulation, make it difficult to create uniform rules.

The author focuses on the different approaches to the conflict regulation of inheritance by law in bilateral international agreements on legal assistance. In particular, international agreements on legal assistance, which contain conflicting rules on testamentary capacity, give priority not to the law of the state in which the testator resided, but to the law of the state of which the testator was a citizen at the time of making or revoking the will.
After analyzing the provisions of EU Regulation № $650 / 2012$ of 4 July 2012 , attention is drawn to the fact that, as a general rule, the law of the state in which the testator had a permanent residence at the time of death applies to the regulation of inheritance relations. However, the testator has the right to choose the law of the state of which he was a citizen at the time of such choice or at the time of death. This right determines, in particular, the ability of a person to make a will.

As a result, the classification of international agreements in the field of inheritance by will is proposed according to such criteria as: quantitative composition, types of norms contained in such international agreements and their scope.

Key words: inheritance, international agreement, inheritance by testament, international agreement in the field of legal aid. 